\title{
Obstacles to the Implementation of Total Quality Management and Organizational Performance in Private Higher Learning Institutions
}

\author{
${ }^{1}$ Okungu Norah Atieno, ${ }^{2}$ Dr. Ojera Patrick, ${ }^{3}$ Kwama Leonard Ogweno \\ ${ }^{1}$ KCA University, School of Business and Public Management, P.O Box 3207- 40100 Kisumu, Kenya; \\ ${ }^{2}$ Maseno University, School of Business and Economics, Private Bag, Maseno, Kenya:
}

\begin{abstract}
This paper aims to identify the main obstacles to the implementation of Total Quality Management. The study is to test the structural order which would enhance Total Quality Management and at the same time seek to discover the systems sensitivity to the human resources with its ultimate effect on performance. To do so, the findings of a stratified sample size comprising of top management team, academic heads of departments, lecturers, support staff and students was obtained for the study. Structured questionnaires were administered and an interview schedule was arranged for a number of members chosen at random and all class representatives. Secondary data was obtained from the University reports on the Total Quality Management implementation and progress. Descriptive statistics have been used to analyse data. The data has been presented in terms of tables and graphs. The study revealed that the implementation of Total Quality Management in KCA University is facing challenges because members do not yet know how best to implement it. At the same time some members are not aware of Total Quality Management principles and do not understand how it works. The study only relied on an accessible sample within the University and was based on their word not considering the fact that sometimes people would respond depending on what they think you want to hear and not sincerely. The result of this study does not only identify the obstacles of TQM but also provides a reference to the managers of this learning institutions as well as the wider business world. The research provides a direction for both TQM scholars and managers and it can serve as a roadmap and a challenge to quality driven organizations.
\end{abstract}

Key Words:Total Quality Management,

\section{Introduction}

By 1991, 93 per cent of manufacturing companies and 69 per cent of service companies had implemented some form of quality management practices. Despite this large and still growing interest in quality management, however a recent study of Total Quality Management (TQM) effectiveness conducted by Soltani et al. (2003) found that less than a third of the respondents rated their Quality Management initiatives as having been "reasonably" or" very" successful with other respondents providing a neutral or in a minority of cases, a negative evaluation. (International Journal of operations \& Production Management). In the past few years, a growing number of learning institutions faced with mounting challenges of declining enrolments, cost containment and public pressure for accountability, have sought improved performance by joining industry in adapting the quality management approaches of quality authorities such as Deming (1986), Juran, Gryna and Bingham (1979), and Ishikawa (1990). The American Council on Education (1993) found that 70 per cent of higher education institutions are using Total Quality Management (TQM) techniques. Higher education has taken a different dimension in Kenya today. Since it is very important to provide quality higher education, the institutions have been working on measures to improve the quality of their services and products. The institutions are important for various reasons such as providing human capital, offering learning opportunities and providing avenue for research and development. Considering the fact that higher education is being driven towards commercial competition imposed by economic forces resulting from the development of global education markets and the reduction of government funding. They are now forced to seek other financial sources and must try by all means to provide high quality services.

\section{A review of TQM Literature}

Owlia and Aspinwall (1996) examined the views of different professionals and practitioners on the quality of higher education and concluded that customer orientation in higher education is a generally acceptable principle. With the changes in the environment the management of learning institutions is presenting very unique challenges and opportunities. This can be seen in the regular changes in the curriculum at all levels of education. Even though the government owns some of the learning institutions there are a number that are privately owned. The private institutions are self funded and face a lot of competition, which make them put in 
consideration how well they would continuously improve the quality of service they offer. As a result most of them have tried different quality improvement models such as Total Quality Management (TQM), Just in Time (JIT) and Kaizen (Continuous improvement). Total quality Management has been one of the models tried. Although higher education institutions are increasingly adopting quality management practices, there is evidence that many institutions are struggling with the implementation challenges. If educational institutions do not overcome these challenges, they will not sustain their quality management efforts and achieve anticipated results. (Innovative Higher Education, Vol 20, No. 1 1995)

\section{Management of Higher Learning Institutions in Kenya}

The education sector has a major role to play in the development of the Kenyan economy. The establishment of private universities in Kenya and Africa as a whole is relatively new. At independence there were about seven universities in Africa. However by 2005 there were eighty five and 316 public universities in Africa, Kihara (2005). Kenya is leading in this expansion of private higher learning institution in East Africa with sixteen in the year 2006 compared to three in 1980. This article is to examine how these institutions can be able to overcome the obstacles in achieving quality management which has been a challenge to many universities. KCAU has taken the initiative to ensure that quality management is practiced. The current practice is that all the departments' work towards achieving the best quality.

There have been performance appraisals that are done every six months and each employee is rated based on his performance. Targets are set and employees are motivated to achieve them.

Quality is maintained in finance, academic, human resource, research and development. The organization defines what it does, services provided and an avenue for customers to question the performance of the university. All the members are expected to be responsible and accountable to the university. This is described in the mission statement which addresses the need of diverse stakeholders such as undertaking research, providing quality general academic and career focused learning opportunities, offering relevant learner support with the help of information and communication technology, creating conducive working and learning environment, contributing to a good and responsible society by imparting moral values for sustainable individual and societal development, participating in his social responsibility activities and meeting the needs of the global competitive society.

The main strategic issues here are what Quality of education are we going to provide, to whom are we going to provide this and how will we be the best in the industry or how will we compete effectively? In the past learning institutions did not think about quality management since it was assumed as the culture of all of them. Due to political, economic social and technological challenges facing the education industry its important to redirect strategies towards ensuring quality production and working on issues that may hinder effective quality management.

\section{Statement of the problem}

The private higher learning institutions provide opportunities for students who cannot access places in the few public learning institutions as well as a way of creating human intellectual capital, providing avenue for research and development. In Kenya there are 20 private Universities as compared to 7 public universities. Therefore, there is intense competition among the private institutions. Each one of them is working on achieving maximum quality possible both on the services and products offered. As a result some have opted for the adoption of Total Quality Management. Despite the widespread use of Total Quality Management still most organizations have not achieved the expected performance such as high enrolment, minimum labour turnover, elimination of conflicts within management and maximum employee motivation. However it is not clear why this undesirable situation persists.

Even though Total Quality Management has been applied in some institutions of higher learning and has experienced a number of challenges such as low enrolment, high labour turnover and even low morale among employees. The focus of this study is to identify the main obstacles to the implementation of Total Quality management. Previous studies have been done on Total Quality Management and its impact in different organizations; however, little research has been done to determine the main obstacles in the implementation of Total Quality Management in private higher institutions.

A primary concern among survey-based researchers has been the issue of what makes Total quality Management work. There are instances of failure to the implementation of Total Quality Management or problems in the implementation of Total quality management in different organizations and especially in learning institutions where researchers have not ventured enough to identify the obstacles in Total Quality Management implementation. This brings us to the question as to why Total Quality Management implementation fails especially in higher learning institutions. The study therefore seeks to determine the obstacles in the implementation of Total Quality Management practices in higher learning institutions with specifics to KCA University. 


\section{Purpose of the study}

The study was to determine the obstacles in the implementation of Total Quality Management processes within higher learning institutions with specific attention to KCAU. The general objective of the study was to investigate the main obstacles in Total Quality Management implementation especially in KCA University in reference to identifying the key obstacles to the realization of Total Quality Management implementation in KCA University, to determine how control the effects of the obstacles on organizational performance and to find out ways of overcoming these obstacles.

\section{Methodology}

A cross- section research design was used in which samples from different groups were picked to indicate particular characteristics at a particular period of time. It was chosen because it was the most appropriate given that it was affordable and data can be quickly collected. Moreover the results obtained from the sample can be generalized to the entire KCA University population. Furthermore the characteristics of the variables measured take a longer time to change. It involved administering questionnaire and survey questions to a sample of KCA university employees and students.

The study was conducted in KCA University at the Main Campus in Nairobi, Kisumu Campus and the Kericho and Eldoret affiliated colleges. KCA is a private university offering certificate, diploma and undergraduate courses.

The research was carried out in all the university campuses an. The population composed of 412 employees of the university and 3500 students. The sample population size was 54 administration staff, 276 lecturers, 82 support staff and 1050 students. Given the small population the researcher used questionnaires and an interview schedule. The dimensions used were administration, lecturers, support staff and students. Thereafter a random sampling technique was used to identify the respondents except for the administration where all of them were given questionnaires. Finally a total of 1234 respondents emerged.

An interview was arranged for the Deputy Vice Chancellors, Directors, Heads of departments, 30 lecturers chosen at random, 20 employees and class representatives.

Table 1 : A table indicating the category, population nand sample size selected.

\begin{tabular}{|l|l|l|}
\hline Category & Population & Sample size \\
\hline Administration & 54 & 54 \\
\hline Lecturers & 276 & 100 \\
\hline Support staff & 82 & 30 \\
\hline Students & 3500 & 1050 \\
\hline
\end{tabular}

To achieve the objectives of this study, primary was collected from the various departments. Secondary data was collected from the university reports on the progress of TQM implementation and Minutes of TQM meetings.

A questionnaire was administered to the top management, middle and lower level managers, supervisors, lecturers, employees and a percentage of the student population. Interview schedule was also organized where 10 management staff was selected to represent the various departments and 30 lecturers picked at random.

Preliminary techniques such as frequencies, distributions and percentages were used for data evaluation. Descriptive statistics particularly the mean and standard deviations were also used to summarize both qualitative and quantitative data. Pearson's' product moment correlation was used to test the relationship between TQM applications Processes and performance. The data was presented using graphs and charts.

Data was also collected through interviewing a number of staff and student representatives.

\section{Findings}

This section presents the results of the study.

Table 2: Indicating Customer satisfaction as per the students

\begin{tabular}{|l|c|r|r|}
\hline Attributes & Lecturer Evaluation & Quality improvement & Proper Supervision \\
\hline percentage & 34.39 & 31.21 & 34.24 \\
\hline Std Devn & 1.01 & 2.21 & 1.38 \\
\hline
\end{tabular}

As indicated in the table above there was a general view that the institution ensures customer satisfaction and the students indicated variables such as regular lecturer evaluations, quality improvement and proper supervision. During the interview 34 percent of the student leaders mentioned lecturer evaluation as a means of effective customer satisfaction, 31 per cent cited quality improvement in form of availing resources and making adjustment where necessary while another 34 per cent talked of proper supervision they experience in the institution. 
Table 3: Indicating TQM principles practiced as per the staff

\begin{tabular}{|l|c|r|r|}
\hline Attributes & $\begin{array}{l}\text { Interdepartmental } \\
\text { Communication }\end{array}$ & Management Leadership & Collective Decision making \\
\hline Percentage & 42.67 & 38.43 & 18.90 \\
\hline Std Devn & 1.01 & 1.38 & 2.21 \\
\hline
\end{tabular}

As shown in the table above the staff also described the Total Quality Management principles practiced in the institution. During the almost 43 per cent indicated that that interdepartmental communication is promoted, 38 per cent agree that there is management leadership experienced by the staff and only 19 per cent think that collective decision making is practiced.

During the interview other issues also came up where employees mentioned the benefits of TQM such as efficiency, improved team work, improved quality and even acceptance of responsibility among members of the institution. Among the staff lecturers tend to think that the whole process is one sided and the students do not understand what its all about and this is one of the reasons why sill TQM implementation is facing hurdles. Not everybody in the organization knows what is happening.

Employees also indicated that as much as they are informed of what is required they are not well trained hence they are not well prepared for the changes that affect them during implementation and this may result in resistance to the implementation of TQM.

Generally there were mixed reactions coming from employees where some have the fear of unknown and the rest are very cautious of what they involve in within the organization. As concerns organizational policies the implementation of TQM as affected to some extent the policies of the organization but the employees can not say the specifics. None of them reported any changes in the organizational structure that they were aware of. They also indicated that TQM has not helped much in achieving organizational objectives yet.

\subsection{Analysis of Data:} university:

The following table summarizes the Students' opinion on satisfaction with services offered by the

Table 4: A table of percentage level of student satisfaction with services offered.

\begin{tabular}{|l|l|l|l|l|l|l|}
\hline Attribute & $\begin{array}{l}\text { Very } \\
\text { Dissatisfied }\end{array}$ & $\begin{array}{l}\text { Somewhat } \\
\text { Dissatisfied }\end{array}$ & Neutral & Satisfied & $\begin{array}{l}\text { Very } \\
\text { Satisfied }\end{array}$ & No Response \\
\hline Percentage & 16.75 & 18.69 & 29.62 & 25.33 & 7.66 & 1.94 \\
\hline Std Devn & 5.15 & 4.65 & 4.11 & 5.03 & 2.09 & 2.20 \\
\hline
\end{tabular}

This gives the following chart.

\section{Student Satisfaction Level}

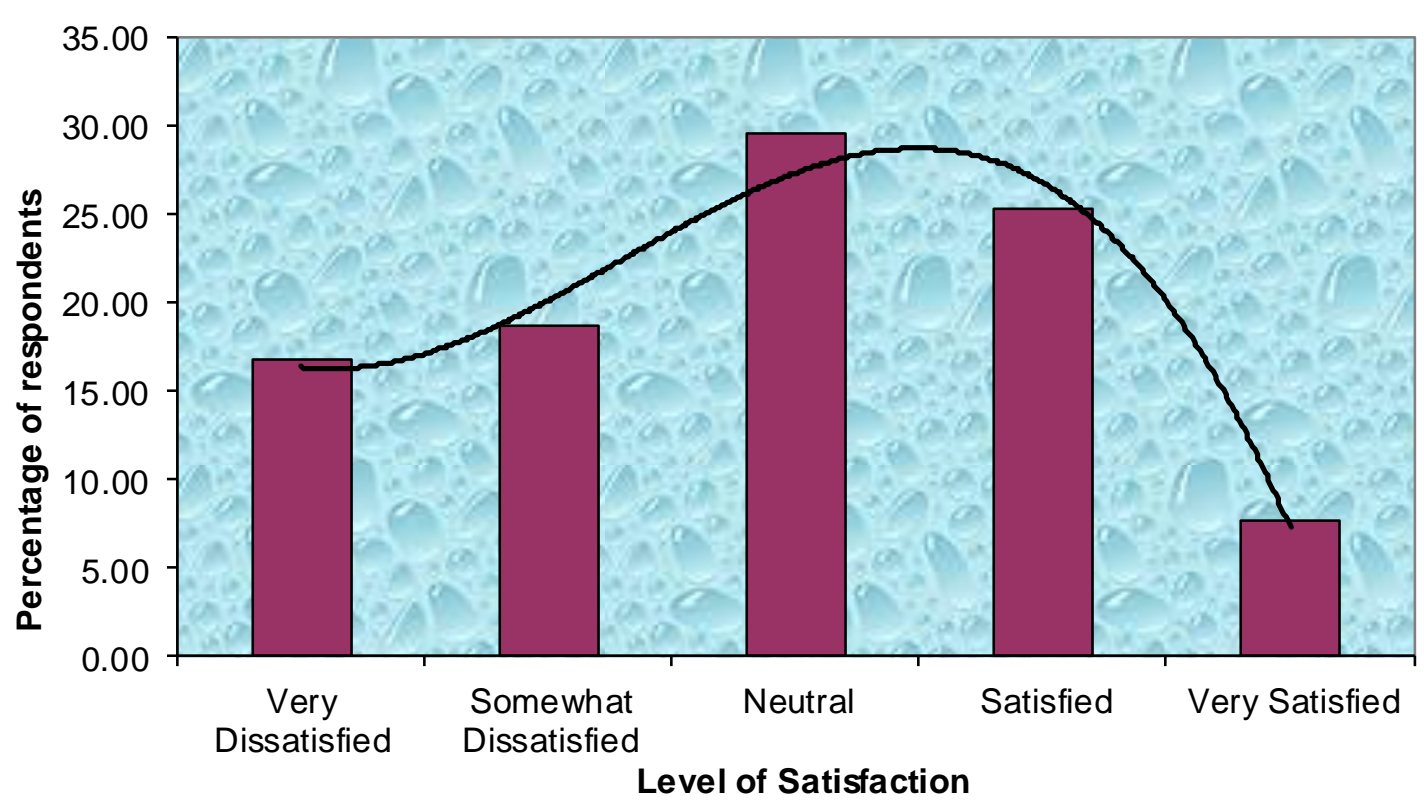

re 1: A bar chart on percentage level of student satisfaction with services offered. 
From the table and the chart above, only 30 percent of the students are either satisfied or very satisfied while $30 \%$ are indifferent and 40 percent generally dissatisfied. This casts a question on the success of implementation of TQM principles. The percentages show below average success and therefore bring in the question of finding out what obstacles hinder the implementation of Total Quality Management as described in the objectives.

Lecturing Staff Opinion:

1. On the level of adoption of TQM practices.

Table 5: A table of percentage level of adoption of TQM services as per staff opinion.

\begin{tabular}{|l|l|l|l|l|l|l|}
\hline Attribute & $\begin{array}{l}\text { Strongly } \\
\text { Disagree }\end{array}$ & Disagree & $\begin{array}{l}\text { Don't } \\
\text { Know }\end{array}$ & Agree & $\begin{array}{l}\text { Strongly } \\
\text { Agree }\end{array}$ & $\begin{array}{l}\text { No } \\
\text { Response }\end{array}$ \\
\hline Percentage & 10.23 & 24.62 & 17.05 & 36.74 & 10.23 & 1.14 \\
\hline Std Devn & 2.42 & 2.81 & 1.70 & 4.00 & 2.25 & 0.65 \\
\hline
\end{tabular}

The following chart explains the lecturers' perception.

\section{Adoption of TQM Practices}

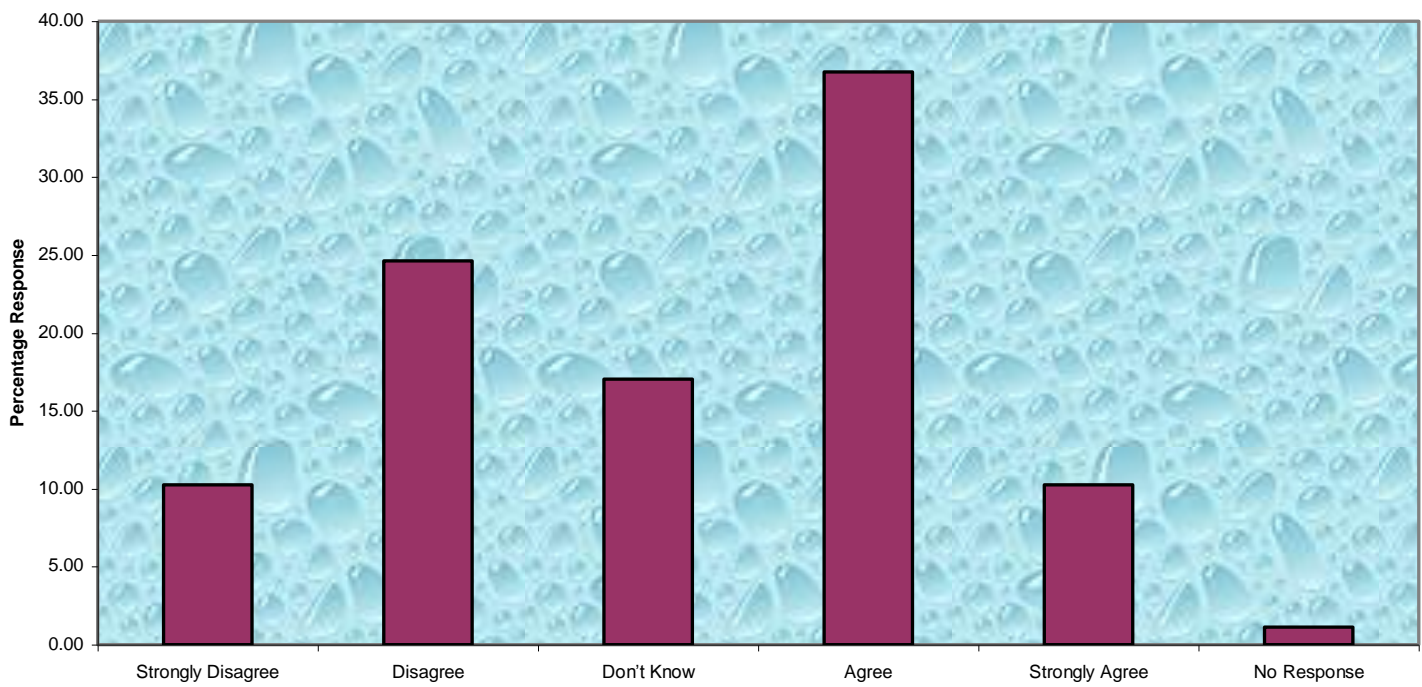

Fig. 2: A bar chart on percentage level of adoption of TQM as per lecturer opinion.

Generally as shown both in the table and graph over 47 percent agree that the TQM practices enumerated in the questionnaires have been adopted. 17 percent are indifferent while the rest (35\%) disagree. To a good extent we conclude that TQM principles have been adopted by the university management, however there are hurdles in the process that must be worked on to define how these obstacles can be achieved as outlined in the objectives.

\section{Extent of implementation of TQM practices}

Table 6: A table of percentage extent of implementation of TQM procedures as per lecturer opinion.

\begin{tabular}{|l|l|l|l|l|l|l|}
\hline Attribute & No Extent & $\begin{array}{l}\text { Little } \\
\text { Extent }\end{array}$ & $\begin{array}{l}\text { Moderate } \\
\text { Extent }\end{array}$ & $\begin{array}{l}\text { Great } \\
\text { Extent }\end{array}$ & $\begin{array}{l}\text { Very Great } \\
\text { Extent }\end{array}$ & $\begin{array}{l}\text { No } \\
\text { Response }\end{array}$ \\
\hline percentage & 9.85 & 26.52 & 28.79 & 23.48 & 9.85 & 1.52 \\
\hline std devn & 1.75 & 4.13 & 2.66 & 2.46 & 2.01 & 0.67 \\
\hline
\end{tabular}

The chart describing this is as follows 


\section{Extent of implementation of TQM Practices}

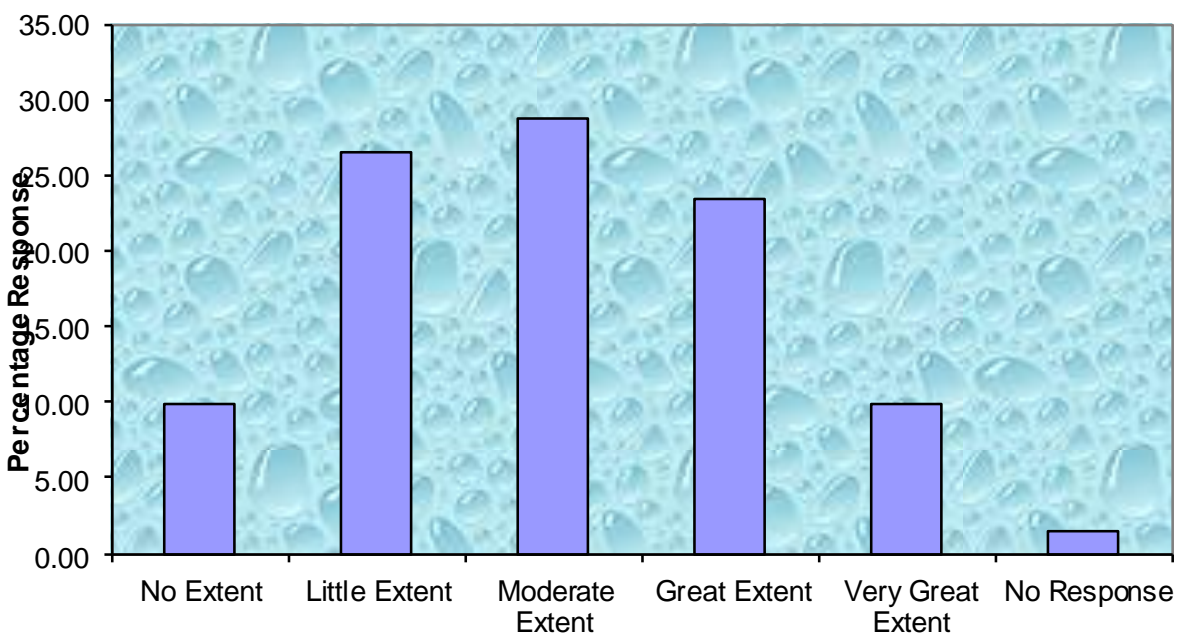

Figure 3: A bar chart on percentage extent of implementation of TQM procedures as per Lecturer opinion.

As shown both in the table and graph the extent of TQM procedures implementation is averagely moderate with over $33 \%$ of the lecturers agreeing that the procedures have been implemented. However $35 \%$ of them feel that little to no implementation of the procedures has been done. This shows that there are still obstacles experienced in the implementation which need to be overcome. This is portrayed in experiences such as lack of leadership and conflict in management experienced in different organizations.

\section{Lecturer opinion on the level of success of TQM Practices:}

Table 7: A table of percentage level of success of TQM practices as perceived by lecturers.

\begin{tabular}{|l|l|l|l|l|l|l|}
\hline Attribute & No Extent & Little Extent & $\begin{array}{l}\text { Moderate } \\
\text { Extent }\end{array}$ & $\begin{array}{l}\text { Great } \\
\text { Extent }\end{array}$ & $\begin{array}{l}\text { Very Great } \\
\text { Extent }\end{array}$ & $\begin{array}{l}\text { No } \\
\text { Response }\end{array}$ \\
\hline percentage & 8.33 & 25.00 & 28.03 & 25.38 & 12.12 & 1.14 \\
\hline std devn & 0.89 & 2.53 & 1.49 & 2.12 & 1.14 & 0.47 \\
\hline
\end{tabular}

A descriptive chart for this information is as follows.

\section{Success in Adoption of TQM Practices}

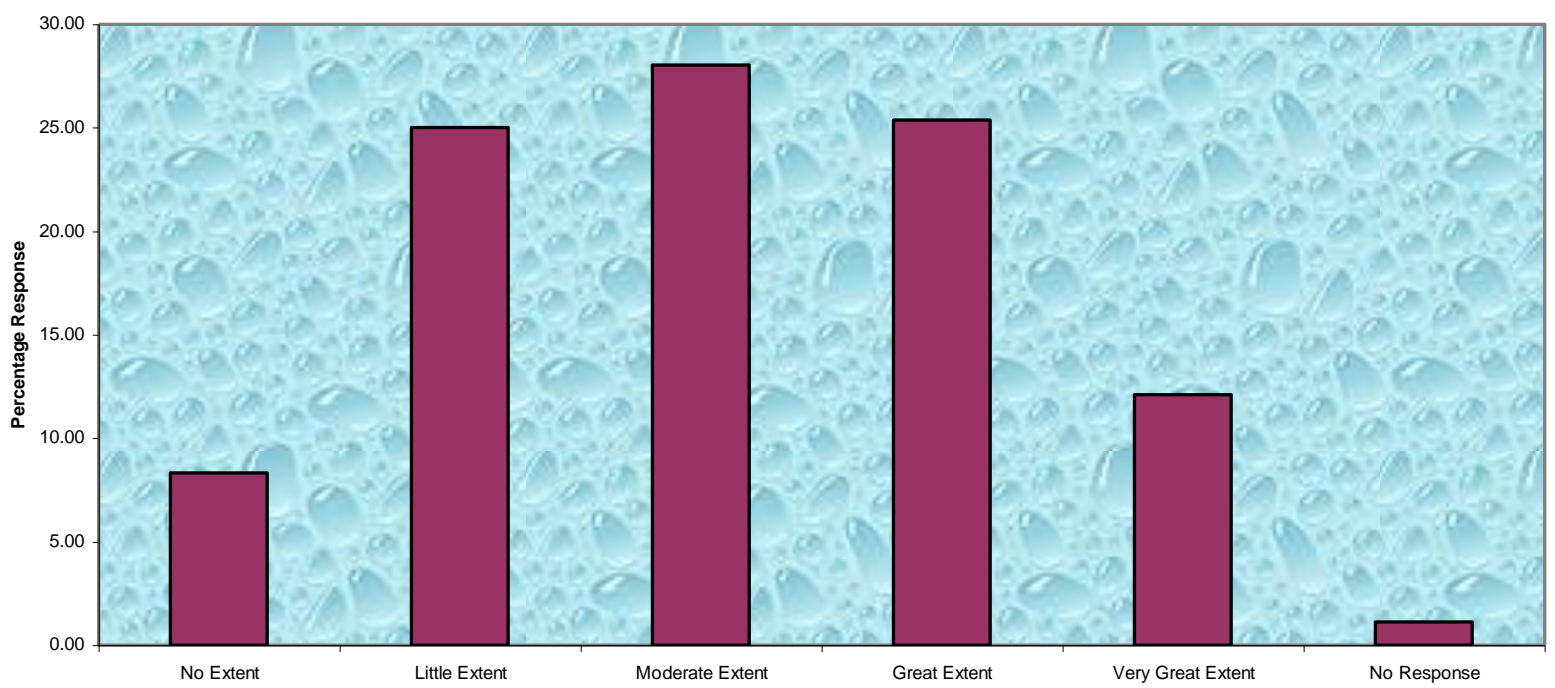

Figure 4: A bar chart on percentage level of success of TQM practices as perceived by lecturers. 
The extent of success TQM procedures is also averagely moderate with over $37 \%$ of the lecturers agreeing that the procedures have been successful. Conversely, $32 \%$ of them feel that there is little to no success of the TQM practice. This in relation to the objectives shows that the challenges that are experienced are being managed effectively and with proper training, communication and leadership TQM will be a success.

\section{The Administration's Opinion:}

\section{On the level of adoption of TQM practices.}

Table 8: A table of percentage level of adoption of TQM practices as per the administrative staff.

\begin{tabular}{|l|l|l|l|l|l|l|}
\hline Attribute & $\begin{array}{l}\text { Strongly } \\
\text { Disagree }\end{array}$ & Disagree & Don't Know & Agree & $\begin{array}{l}\text { Strongly } \\
\text { Agree }\end{array}$ & $\begin{array}{l}\text { No } \\
\text { Response }\end{array}$ \\
\hline percentage & 9.09 & 20.45 & 13.64 & 38.64 & 13.64 & 4.55 \\
\hline Std Devn & 1.04 & 1.44 & 1.69 & 2.29 & 1.12 & 0.52 \\
\hline
\end{tabular}

This has been used to construct the chart in Figure 5

\section{Adoption of TQM Practices}

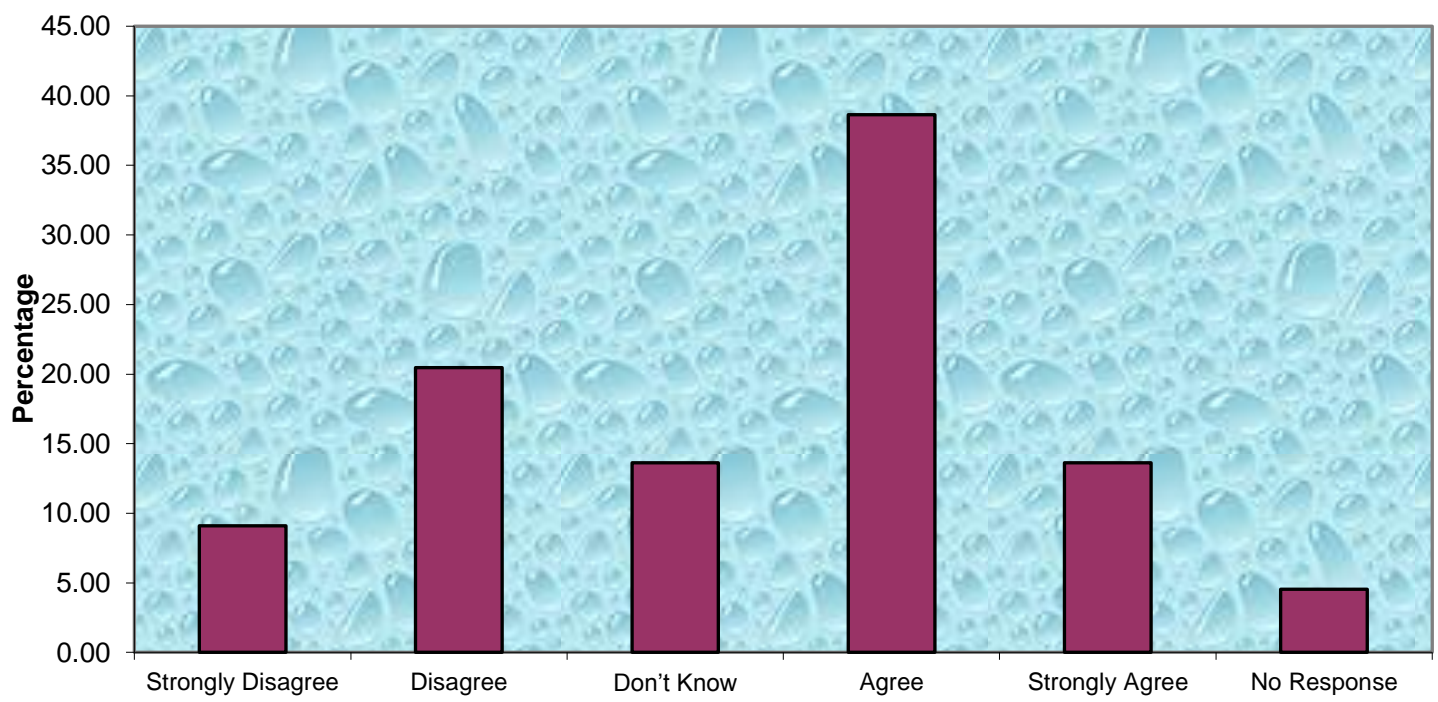

Figure 5: A bar chart on percentage level of adoption of TQM practices as per the Administrative staff.

From the graph and the chart we note that over 52 percent of the managing staff feel that TQM practices have been adopted. Only 13 percent are indifferent. However 29 percent are not upbeat in the level of adoption. Comparing this with lecturer opinion, we see a slight difference of opinion. The administrators agree more than lecturers on the level of adoption of the practices. At this point the lecturers tend to be the hurdle in adopting TQM practices and therefore there is need to make the lecturers understand the need of TQM. As TQM affects the whole organization if the lecturers are left behind the organization would not achieve its objectives. It therefore means that lecturers' indifference is an obstacle in implementing Total Quality Management principles.

2. Extent in implementation of TQM procedures.

Table 9: A table of percentage level of implementation of TQM practices as per administrative staff opinion.

\begin{tabular}{|l|l|l|l|l|l|l|}
\hline Attribute & No Extent & $\begin{array}{l}\text { Little } \\
\text { Extent }\end{array}$ & $\begin{array}{l}\text { Moderate } \\
\text { Extent }\end{array}$ & $\begin{array}{l}\text { Great } \\
\text { Extent }\end{array}$ & $\begin{array}{l}\text { Very Great } \\
\text { Extent }\end{array}$ & $\begin{array}{l}\text { No } \\
\text { Response }\end{array}$ \\
\hline percentage & 14.39 & 21.21 & 24.24 & 19.70 & 11.36 & 9.09 \\
\hline Std Devn & 1.01 & 2.21 & 1.38 & 2.06 & 1.29 & 0.30 \\
\hline
\end{tabular}




\section{Extent of implementation of TQM Practices}

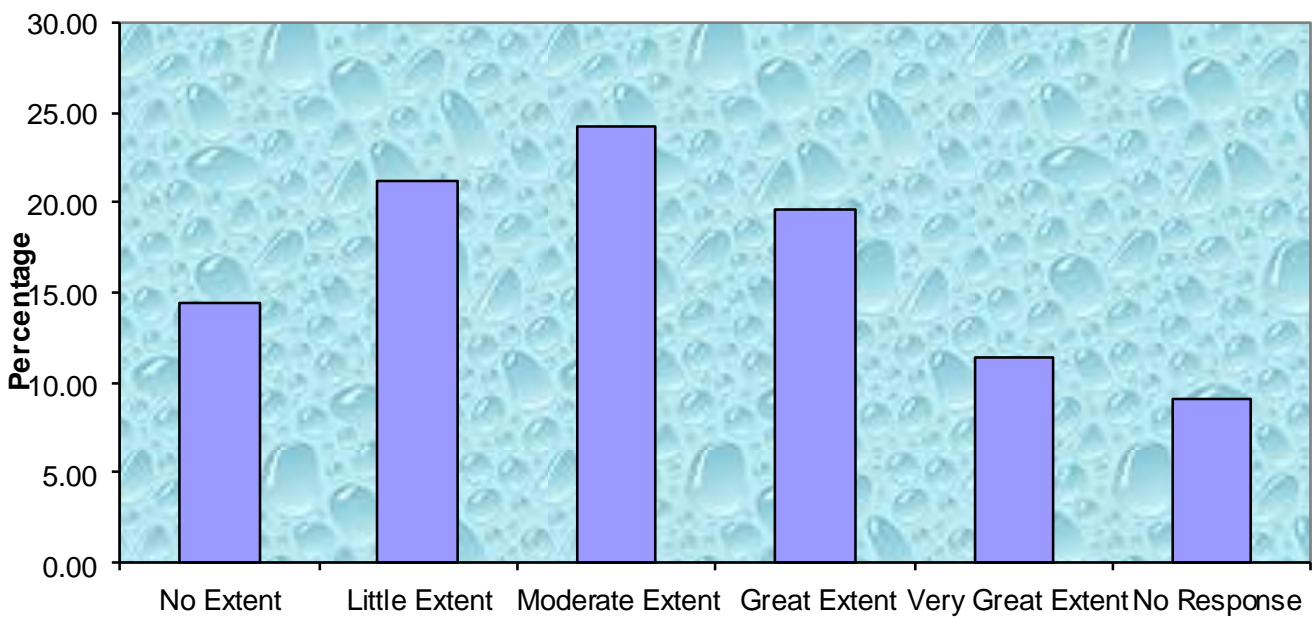

Figure 6: bar chart on percentage extent of implementation of TQM practices as per administrative staff opinion.

The extent of TQM procedures implementation is averagely moderate with over 24 percent of the administrators agreeing that the procedures have been implemented. However 35 percent of them feel that little to no implementation of the procedures has been done, while 31 percent give the extent as great and very great. This means a majority do not agree that Total Quality Management has been applied. If the employees do not agree on whether TQM is being practiced or not shows that they may not be fully involved and therefore it can not be a success because it requires the efforts of all the members of the organization and that brings us to the objective of how to overcome the obstacles experienced in TQM implementation.

3. Extent of success on implementation of TQM procedures:

Table 10: A table of percentage extent of success on implementation of TQM procedures as per administrators' opinion.

\begin{tabular}{|l|l|l|l|l|l|l|}
\hline Attribute & No Extent & $\begin{array}{l}\text { Little } \\
\text { Extent }\end{array}$ & $\begin{array}{l}\text { Moderate } \\
\text { Extent }\end{array}$ & $\begin{array}{l}\text { Great } \\
\text { Extent }\end{array}$ & $\begin{array}{l}\text { Very Great } \\
\text { Extent }\end{array}$ & $\begin{array}{l}\text { No } \\
\text { Response }\end{array}$ \\
\hline percentage & 11.36 & 18.94 & 34.09 & 16.67 & 9.85 & 9.09 \\
\hline Std Devn & 0.81 & 1.35 & 1.30 & 1.34 & 1.08 & 0.30 \\
\hline
\end{tabular}

\section{Extent of Success of TQM Practices}

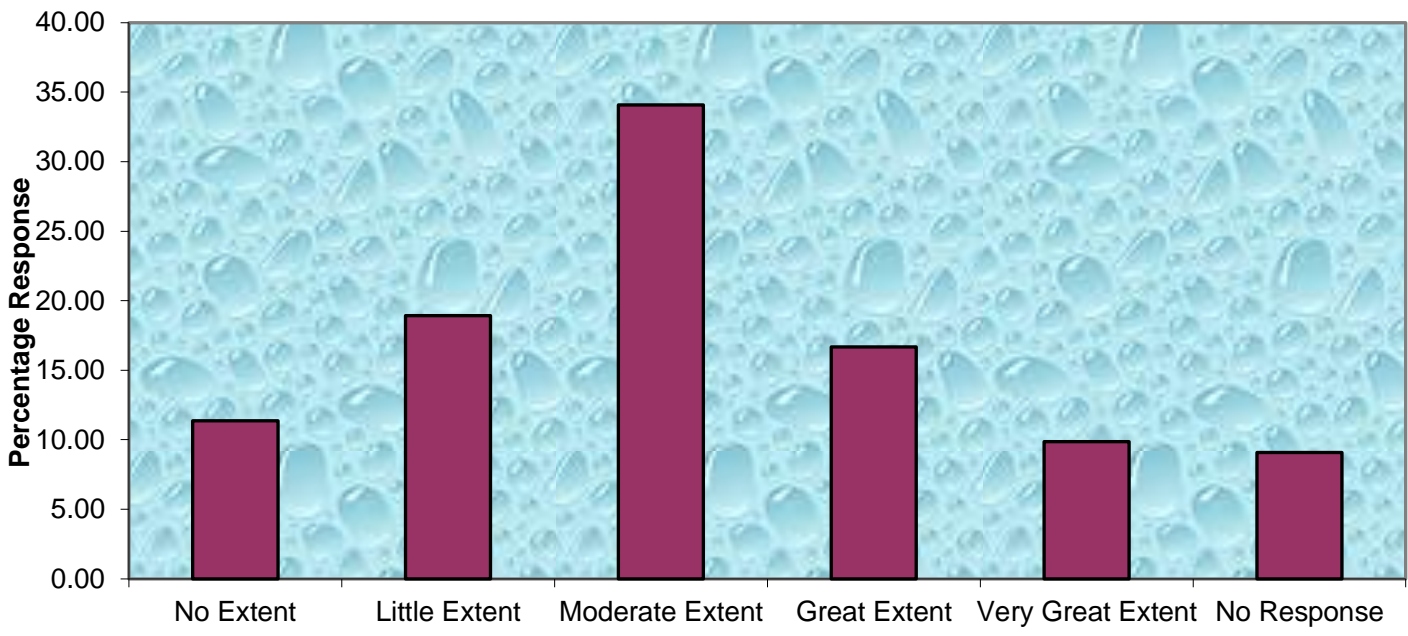

Figure 7: A bar chart on percentage extent of success on implementation of TQM procedures as per administrators' opinion. 
As shown above in the table and graph above the extent of success of TQM procedures is also averagely moderate with over 35 percent of the administrators agreeing that the procedures have been successful while 30 percent of them feel that there is little to no success of the TQM practices. 35 percent is not a majority and therefore there is still a problem in implementation success meaning that the obstacles in successful implementation are being felt. These could be lack of training, inadequate information and even poor leadership skills.

Correlation Analysis:

Table 11: A table to compare student level of satisfaction with the administrations claim of success.

\begin{tabular}{|l|l|l|}
\hline Pearson's Product Correlation Coefficient. & Student satisfaction & Administrator success claim \\
\hline Student satisfaction & 1 & 0.821946 \\
\hline Administrator success claim & 0.821946 & 1 \\
\hline
\end{tabular}

There is a high correlation of opinion between the two parties. This means that the two groups agree to a large extent on the success of TQM practices.

Table 12: A table comparing the student satisfaction with the level of implementation of TQM practices we have:

Source: Author.

\begin{tabular}{|l|l|l|}
\hline Pearson's Product Correlation Coefficient. & Student satisfaction & Level of implementation \\
\hline Student satisfaction & 1 & 0.940103 \\
\hline Level of implementation & 0.940103 & 1 \\
\hline
\end{tabular}

Again, there is a high correlation of opinion between the two parties. This means that there is a similar feeling about the level of implementation of TQM practices.

Table 13: A table showing the correlation of adoption, implementation and success as perceived by lectures and administration.

\begin{tabular}{|l|l|l|l|}
\hline $\begin{array}{l}\text { Pearson's Product Correlation } \\
\text { Coefficient. }\end{array}$ & Administration on Adoption & $\begin{array}{l}\text { Administration } \\
\text { implementation }\end{array}$ & on \\
\hline Lecturer on Adoption & 0.96325 & & \\
\hline Lecturer on implementation & & 0.980195 & \\
\hline Lecturer on success & & & 0.793028 \\
\hline
\end{tabular}

It is also noted that lecturers agree with the administration on adoption and implementation of TQM practices although there is a slight disparity on the level of success of the practices.

\section{Conclusions}

It can be concluded that Total Quality Management is being practiced in KCA University but the different people affected do not agree on how it is being implemented and how it should be implemented. The top management argues that its being the way it should while the lecturers and the support staff have a different opinion. As concerns the students there are a number who are not sure of what is going on while there are those who are satisfied with the services as well as dissatisfied. It therefore shows that Total Quality management has not made the ultimate impact ad is still experiencing some obstacles in its implementation.

The research explores the relationship between Total Quality Management and organizational performance and concluded that principles such as feedback for continuous improvement, top management support, employee involvement, employee empowerment and customer focus are directly related to level of student satisfaction, staff motivation, improved student enrolment, low labour turnover and team work.

\section{References}

[1]. Ashok, R. (1996). Total Quality Management. Across Functional Perspective, New York, Donnelley/Crawford's Ville.

[2]. Association of Commonwealth universities (2005) commonwealth Universities Yearbook $79^{\text {th }}$ Edition

[3]. Barrie G. Dale (2006), Managing Quality.4th Edition Christopher \& Larker (W.P 96-01). Quality Strategy, strategic control systems and organizational Performance. The Wharton school University of Pennsylvania Philadelphia.

[4]. Collins B.G (1995) Dictionary of Sociology.

[5]. Creg Bounds, Gipsy Ranney, Lyle Yorks \& Mel Adams (2004). Total Quality Management (Toward the emerging Paradigm).

[6]. Fred R. David, Strategic Management. (Concepts and Cases)

[7]. Heinz Wehrich \& Harold Kootnz (2001). Management (A global Perspective). 10th Edition.

[8]. Innovative Higher Education (1995), Vol 20

[9]. Ishikawa Kaoru (1984) Guide to Quality Control. $2^{\text {nd }}$ Edition.

[10]. Ishikawa Kaoru (1988) The pursing Performance. $1^{\text {st }}$ Edition

[11]. James G. March (1991) Organizational Learning. $1^{\text {st }}$ Edition 
[12]. James, W.D \& Bowen D.E., Management Theory and Total Quality. (Improving research and practice through Theory Development). The Academy of Management Review, Vol 19 (July 1994 PP392-392)

[13]. Joel, R.E (1990), Total Quality Management. USIU

[14]. John A. Pearce 11 and Richard B. Robinson Jnr. Formulation, Implementation and control. $9^{\text {th }}$ Edition

[15]. John Butman \& Juran, J.M (1997), Quality \& a Century of Improvement

[16]. Juran, J.M \& Kenneth S. Stevens (2000), Overcoming Resistance to Organizational Change.

[17]. Juran, J.M (1997), A lifetime of Influence

[18]. Juran, J.M (1992), Quality by Design. The new steps in planning quality into goods and services. New York, the Free Press (McMillan, Inc)

[19]. Laurie J. Mulins. Management and Organizations. $4^{\text {th }}$ Edition.

[20]. Olive, M. Mugenda (2003). Research Methods Quantitative and Qualitative approaches, Nairobi ACTS Press 1999.

[21]. Pearce \&Robinson (2005), Strategic Management. New York, McGraw Hill.

[22]. Tom Peters \& Nancy Austin (1986), A Passion for Excellence. New York, Boston, Warner Books- USA.

[23]. Thomas C. P., Total Quality Management Implementation and Competitive Advantage. A Review and Empirical Study. Strategic Management Journal Vol. 144 No. (1 February 2001)

[24]. Thomas T. J. and Waterman R. H (2006), In Search of Excellence. New York, Boston, Warner Books- USA

[25]. T. N. Chhabra. Principles and Practices of Management. $2^{\text {nd }}$ Edition

[26]. Uma Sekaran, (2003). Research Methods for business. 4th Edition Southern Illinois University, John Wiley \&Sons Inc

[27]. Wentland, E.J. \& Smith, K.W (1993). Survey Research Methods. University of Chicago Press. 